\title{
Sharing Life Experiences of Teenage Girl Delinquents through Life Map Sketch
}

\author{
Zuhda Husain $^{1}$, Sh Marzety Adibah, A.S.M. ${ }^{2}$ \& M.S. Nor Shakirah ${ }^{1}$ \\ ${ }^{1}$ School of Social and Economic Development, Universiti Malaysia Terengganu, 21030 Kuala Nerus, \\ Terengganu, Malaysia \\ ${ }^{2}$ Pusat Islam Sultan Mahmud, Universiti Malaysia Terengganu, 21030 Kuala Nerus, Terengganu, Malaysia \\ Correspondence: M.S. Nor Shakirah, School of Social and Economic Development, Universiti Malaysia \\ Terengganu, 21300 Kuala Terengganu, Terengganu, Malaysia. E-mail: shakirahsakari@yahoo.com.my
}

Received: February 12, $2017 \quad$ Accepted: March 11, $2017 \quad$ Online Published: April 19, 2017

doi:10.5539/ass.v13n5p68 URL: https://doi.org/10.5539/ass.v13n5p68

\begin{abstract}
Life map sketch is a unique technique of an expressive therapy that can be used in the process of emotional healing for clients. The purpose of this study was to explore the life experiences of teenage girls engaged in delinquent behaviour using life map sketch. Seven teenage girls from one approved school in Malaysia were selected in this study using purposive sampling. The result showed that there were some themes identified from the teenage girls delinquent sharing of life experience in this study. The themes were hardship, expression of emotion, negative behavior, meaning behind the sketch and hopeful. The use of life map sketch's technique help the participants in expressing their latent issues that they found hard to express orally. Therefore, this technique is very promising in improving the counseling services in Malaysia.
\end{abstract}

Keywords: teenage girl, delinquent, life map sketch, expressive arts therapy

\section{Introduction}

Nowadays, social problems or delinquency is no longer a strange thing to be heard. Delinquency is a major concern worldwide includes Malaysia. Instead, it is seen as a symptom that is widespread rapidly among adolescents in line with modernisation and technology. Delinquency refers to adolescents who break the law (Ahmed Sorour, \& El Badawy, 2014). Capaldi and Shortt (2003) explained that delinquent behavior is included in the classification of abnormal behavior. Delinquent behavior may start from a less severe wrongdoing, for instance violation of school rules such as truancy, smoking and vandalism to more serious crimes such as theft, robbery, drugs, rape, possessing weapons (Choon, Hasbullah, Ahmad, \& Ling, 2013; Jung \& Choi, 2017), sexual activities, baby dumping, illegal racing (Sh Marzety Adibah, Melati, \& Zuria, 2013) and the list goes on.

Statistics from the Department of Social Welfare has shown an increase in cases of juveniles from year to year. This increase was a concern and requires the attention of various parties. The cases of adolescents involving in delinquent behaviors in Malaysia has increased from year to year, amounting to 4801 cases reported in 2011 (Department of Social Welfare Malaysia, 2011) which later increased to 6020 cases in 2012 (Department of Social Welfare Malaysia, 2012). The number of teenage girls involved in crime has also increased from 277 reported cases to 406 cases between 2011 and 2012. The data indicated that the involvement of youth in crime and delinquent behavior are becoming more serious. Delinquency among adolescents leads to an adverse effect in community, family (Azmawati et al., 2015) and adolescent itself in terms of safety, physical health, and mental health (Jung \& Choi, 2017).

In counseling, various techniques can be used to help clients, particularly adolescent delinquents such as Expressive Arts Therapy. Expressive Arts Therapy is a therapy that uses various mediums of art and creativity during the treatment process (Estrella, 2005). Expressive Arts Therapy combines several of art such as visual arts, movement, drama, music, writing and other creative processes to foster personal growth and community development. Rowe, Watson-Ormond, English, Rubesin, Marshall, Linton, Amolegbe, Agnew-Brune, \& Eng (2016) defined art therapy as psychotherapy which uses the art-making process to improve social, mental, and emotional well-being. This therapy can be implemented not only in individual counseling or group counseling, but also in family counseling. This approaches also can be applied in many different situations (Riley, 1999). 
In this study, Expressive Arts Therapy is used because it is a less threatening intervention for a child or adolescent (Mousavi \& Sohrabi, 2014). Expressive Arts Therapy is a way for children and adolescents to express their experiences and feelings which they find difficult to express through verbal method. Adolescents are encouraged to explore their responses, reactions, and insights via pictures, sounds, explorations, and encounters with art processes. They have a lot of things to be expressed, but they do not know how to express (Thomas, 2011). Art and creativity are a form of communication that helps young people to avoid the possibility of them harboring ill feelings, or expressing those feelings in a way that could damage themselves (Saunders \& Saunders, 2000). According to Sh Marzety Adibah and Zakaria (2014), the creative arts or expressive arts are a way or path that is comfortable for children and teens to communicate with adults on their internal and external issues. Expressive Arts Therapy techniques help adolescent reflect and share their life stories with other group members but also to give and receive feedbacks as well (Phey \& Lan, 2012).

Most of the results from previous studies have proven that this therapy is very effective in solving various issues and complexities of life experienced by individuals. However, most of them have yet to conduct a study using Expressive Arts Therapy to get the underlying meaning during the therapy process particularly from the perspective of the subjects themselves, who were involved in delinquent behaviors. Moran (2000) believed that the essence of the experience should first be understood before any description about the phenomena is introduced. Thus, this study aims to explore the life experiences of teenage girl delinquents using the life map sketch in Expressive Arts Therapy.

\section{Method}

\subsection{Research Design}

To understand their actual experiences in the researched phenomenon, the phenomenological approach has been chosen as the design of the study. Sabitha (2005) explained that a qualitative research focused on the context of a process and how things happened in an environment (setting) to be studied. Furthermore, it is also suitable for in-depth study of activities, events and processes (Creswell, 2003). Phenomenology design is often used to focus on the life experience of the individual as a way to understand the meaning of a life experience. Apparently, the design of this study is consistent with the research purpose which is to explore and understand in depth the life experiences of seven teenage girls involved in delinquent behaviors while using expressive arts therapy through life map drawing techniques in group counseling sessions. According to Merriam (2002), phenomenology is an approach that focuses on the process of interpreting meaning and purpose of a phenomenal interaction. In general, this study focuses on internal process and phenomenal interactions of delinquent behaviors experienced by the subject; and the interaction with their experience using the therapy to determine the reality, believe that the knowledge is developed internally, as well as finding and maintaining the perspective of individuals studied.

\subsection{Participant}

A total of seven teenage girls between the ages of 16 and 18 who are involved with delinquent behaviors were selected as the participant. These teens were detained and placed in one of approved schools and were selected using purposive sampling. All the participants' name in this study has been changed.

\subsection{Procedures}

In counseling session, members of the group were given a guided imagery, which envisaged a map of the past and current journey in the lives of each member in the group. Members of the group were asked to imagine and express the image on a drawing paper. Then, they were to come up with a life map by using any creative materials that represent their journey in life. The results were then shared with other sketch group members.

\subsection{Data Collection}

Data for this study was collected from several sources such as interviews, observations, artwork sketch map of life and diary writing. The uses of multiple sources of data were a triangulation approach of various sources and data reinforcement (Miles \& Huberman, 1994).

\subsection{Data Analysis}

The data obtained were analyzed through several stages. In the first stage, data analysis was performed simultaneously with the process of data collection. In this context, Merriam (2001), stressed that qualitative data analysis should be done in sync with data collection. The second stage of data analysis was based on phenomenological analysis following the procedures of Giorgi and Giorgi (2003). According to the procedure, five essentials steps were taken, namely the search for meaning as a whole, discrimination of meaning unit, the initial psychological meaning unit transfer, followed by the determination of an individual psychological 
structure and finally synthesize general psychological structure.

For the interview findings, verbatim transcriptions of the chosen interviews were analyzed up to the findings of the themes. As for the mapping experience, all sub-themes were taken and linked to each other based on the experiences of the subjects through visual mapping approach. Ensuing this, the sub-categories or sub-themes for all subjects in this study were reviewed and grouped into categories or themes. A full complete list of categories and sub-themes were then sorted and arranged according to the related category and theme. In this common psychological structure, the subject's overall experiences were combined with other various individual units. Merging the full experience of all subjects for this study has produced common themes or categories that represent a full understanding of the experiences of the subjects' lives. The combination of overall experiences of all subjects in this study has produced a general theme representing a full understanding of the experiences in their lives.

\section{Results}

Overall, five themes were created from the analysis that reflected the experiences of teenage girls engaged in delinquency. The main themes appeared in this research are hardship, expression of emotion, negative behavior, meaning behind the sketch and hopeful.

\subsection{Hard Ship}

\section{Family Conflicts.}

Most of the subjects in this study had hardship in life such as bad experience with biological parents, adoptive mothers and their families. Some of the conflicts that are shared via the sketch map of life are a rocky households and broken marriages that took place between their mother and father. Salina (not real name) shared that her parents had a rocky marriage with domestic upheavals occurring all the time and that their house was burned due to the betrayal of her own father.

"When I was 10 years old, on January 31, 2001...mom and dad got divorced. Mom was divorced with a 3rd talaq". (Salina)

"On 21st April 2001, our house was burnt. Two of my brothers were the victims and their bodies were badly burnt. Investigation revealed the cause was from betrayal". (Salina)

Khaty (not real name) also said that while growing up, her mother and father were always fighting because her father was a drug addict.

"Papa asked for money from mama to buy drugs. Then mama said she had no money...maybe that answer enraged papa thinking that mama ignored him, so he hit, slapped, and kicked her over and over again in front of my eyes, I was just a kid then". (Khaty)

Lily (not real name) also revealed that she was raised in an unstable household where her mother and father had a stormy relationship and Lily's father had married another woman. The upheaval in the family led to Lily's depression and eventually dragged her to delinquent behaviors.

"I also experienced being hit by papa. At the time I was eating with mama near the back door when papa came home and out of nowhere started beating mama using his belt, rubber pipe, pans and anything close to him, he would throw them to mama."(Lily)

Rape and Molestation.

Most of the subjects also shared that they had been raped, and there are also cases of subjects being molested. Zaza (not real name) said she had been gang raped by a group of bikers whom she did not know when she was 16 years old.

"I was raped by a group of punks because they thought I was a bohsia like my adopted sister." (Zaza)

Khaty too disclosed an event in her life that she could never forget through the life map sketch; she was molested by her own father.

"Papa fondled me from down there and made his way up. I woke up and saw him touching my genitals." (Khaty)

"Papa never gives up. Almost every day papa tried to repeat the offense and failed. But unfortunately in the middle of 2004 papa finally succeeded. Papa managed to get what he wanted." (Khaty)

Fifi (not real name) was almost raped by her friend when she was 10 years old. The event is also one of the causes for her suffering since she was accused of wanting to have sex with the boy voluntarily. 
"When I was 9 years old, I was raped by Indian students of the same age. He and his friends had conspired to catch me while I was checking the toilets on the top floor, but only one managed to do it. It was the saddest time for me because I was accused of committing it". (Fifi)

Abuse.

There are also subjects who shared their experiences of being abused. Lily shared her painful experience as she and her mother were being constantly abused by her father.

"I also experienced being hit by papa. At the time I was eating with mama near the back door when papa came home and beat mama using his belt, rubber pipe, pans and anything close to him, he would throw them to mama". (Lily)

Rina (not real name) told that she was abused by her own mother. Her mother dumped her and never acknowledged Rina as her daughter. She suffered emotional disturbance due to the abuse until now. Kamelia (not real name) depicted her experience through a sketch map of life as a victim of abuse by her stepmother. The experience has caused a trauma in her life.

"I always see my mom and dad fighting in the room. I was always afraid she would hit me. Mother always beat me". (Rina)

"When I grew up, I was physically abused by my mother. Mak slapped and pulled my hair ". (Kamelia)

Sexual Intercourse.

Most of the subjects reported that they had had sex with their boyfriends. Kamelia had sex with her boyfriend where she conceived and bore a child out of wedlock. The incident left a painful experience in each of Kamelia's, Khaty's and Zaza's live.

"Almost every day I have sex with my boyfriend". (Kamelia)

"I started to be involved and have sex at the age of 17. For 3 months I had sex repeatedly, and it was consensual and voluntary on my part. I did it with my couple who was of the same age but from a different school. We had sex at my house in the absence of my mother and younger siblings". (Khaty)

"I always have sex with him because we live together in the same house. Sometimes I requested, other times he would request for sex. But mostly he was the one asking for sex". (Zaza)

\subsection{Expression of Emotion}

There are some emotional issues that are shared by the subjects. They expressed feelings of hatred and anger, stress and even trauma. All of these issues were expressed by the subjects in the interviews conducted during the group sessions and in their diary writing.

Disappointment, Hatred and Anger.

Rina said she sometimes experienced feeling sick, depressed, sad and sometimes anger towards everybody.

"I harbor the feeling of anger. It is an attitude of mine since I was a kid until now. It always angers me when I see my mother's face. I hate her because she always beat me for no reason". (Rina)

Fifi disclosed her experiences of seriously getting involved in various delinquent behaviors due to her disappointment, and rebelled against the treatments from her stepmother.

"I started getting involved with social activities beginning from the age of 13 because I was always being scolded by my mom. I became stressed therefore I tried doing something". (Fifi)

"Sometimes I didn't go back for a week. When I returned home, my mother asked me why I didn't come home, I answered that I was stressed listening to her nagging". (Fifi)

Stressed.

Lily expressed that the turmoil in the family has made her depressed and eventually led her to negative activities. Lily turned to her friends to share the problem and was influenced by her friends. Similarly, Rina too turned to her friends when she was stressed and chose her friends for reference which led her astray.

"I like to go out at night, shopping and hanging out with friends". (Rina)

Trauma.

All the abuse experienced by Rina has brought about emotional disturbance until now. The events left a profound effect that made her suffer deeply and traumatised her life. Likewise, the impact of Kamelia's abused also 
traumatised her.

"I have a phobia because of my ex-boyfriend. If I see men, I would not approach them". (Rina)

"My experience of being physically abused was very painful. The first time I was beaten by my older brother...I was beaten so hard it left a scar on my face and body. I was punched, slapped and pulled by the hair". (Kamelia)

\subsection{Negative Behaviors}

Subjects in this study shared about their negative behaviors which brought them into a rehabilitation school. Some of the participant engaged in negative activities like substance abuse, illegal racing, alcohol consumption, and violation of school rules.

Substance abuse.

Most of the subjects involved relayed their experiences with substance abuse such as alcohol, pills, drugs and smoking. Salina drew some other events that took place in her life when she was 11 years old whereby she drank alcohol with friends who lived near to her place. At that age, Salina also took ecstasy pills. Likewise, Khaty and Fifi were also involved in substance abuse of smoking, alcohol and drugs.

"Soon after, I began drinking alcohol following friends who were about the same age." (Salina)

"I dabbled with alcohol when I'm out with the perilous bikers. On weekend at night we would have a drink together. The drug that I had taken was ice baby". (Khaty)

"I used to smoke even at home. I also often went out with friends. I rarely drink alcohol. I would only take alcohol when I was really stressed". (Fifi)

Illegal racing and Perilous Biking.

Khaty's life map sketch also shows her involvement in negative behaviors such as smoking, taking ecstasy pills, illegal racing and having sex with her boyfriend.

Violation of school rules.

Peers are a major influence leading most of the subjects to continue engaging themselves in negative behaviors that are far from the norms of society. Lack of love and attention from family caused Kamelia to start mingling with friends and having a boyfriend.

"I always skip school, classes and go out with my friends. I once joined Gothic with friends. I had run away from home with friends for fear of being scolded by mom for always causing problems at school ..." (Kamelia)

\subsection{Meaning behind the Sketch}

Subjects described their journeys in life using the sketch map of life and shared their life experiences from childhood until they entered the Rehabilitation Centre.

Rose Tree.

Rina portrayed her life journey on a tree which ended with a rose (Figure 1). Rina described her journey on a rose tree with thorns, roots and leaves that represented meanings that linked to her life. Rina has built up expectations in the sketch map of life that one day she will become like a rose, with a scented fragrance and needed by others.

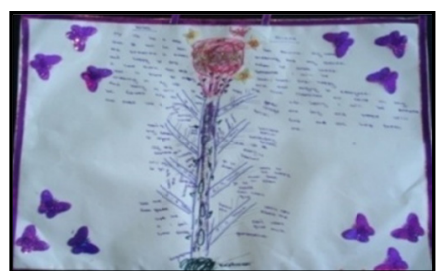

Figure 1. Rina's Sketch Map of Life

Hill.

Kamelia drew a map of her life by declaring her journey as a journey that went up and down the hills (Figure 2) to arrive at its destination. She never knew the meaning of love and affection, resulting Kamelia to lead life on her own which eventually brought her to shame. 


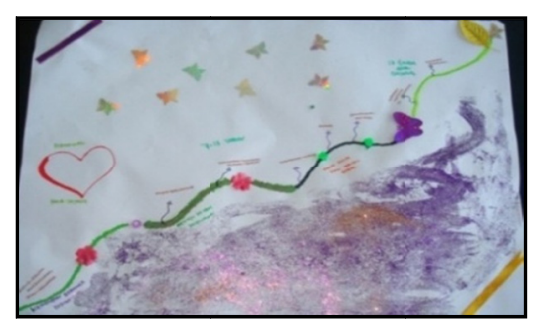

Figure 2. Kamelia's Sketch Map of Life

Roads.

Researchers found that most subjects had put those experiences that they have travelled along the way (Figure 3) which represent the past, present and future. Salina shared her stories with other members of the group based on the creativity of the sketch map of life that she produced. The creativity produced by Salina on the sketch map illustrated her life journey from childhood until she was placed in the rehabilitation center.

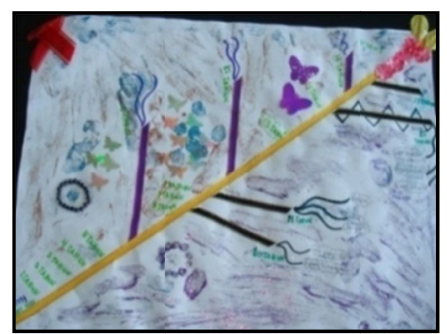

Figure 3. Salina's Sketch Map of Life

\subsection{Hope Expectations}

The subjects also revealed that they felt a shot of new hope after the counseling sessions using the sketch map of life.

\section{Hope Injection.}

Most of the subjects have built up hopes from the detours, obstacles and challenges they faced from their journeys before. Sharing through the sketch map of life has given hopes to the members of the group to continue to share their past experiences, better recognize, understand and get a taste of each other's experience. Rina has shown her hope in her sketch map of life that one day she will become like a rose with a fragrant smell that will always be needed and appreciated by others.

Future Plans.

From the observations, the researchers found that all seven subjects eventually made plans for the future. They realized that there were many mistakes that have occurred in their pasts and they regretted them. They are finally ready for a positive change as the realizations of their past mistakes were laid out in the sketch map of the lives that have been produced.

\section{Discussion}

The findings have shown a description on the scenario of life experiences of the female teenagers involved with delinquent behaviors. This study also gives teenagers chances to tell their stories.

The findings also provide an explanation on the teenagers' experiences through life map sketch technique carried out in expressive arts therapy. Obviously, the results of this study showed that the sketch map technique used in expressive arts therapy offers a non-threatening approach for individuals to express their feelings verbally and nonverbally. In addition, this creative process also allows the teenagers to face the issues and materials consciously and unconsciously. This finding is consistent with the literature by Wilson and Ziomek-Daigle (2013) that stated the use of expressive arts therapy is to bring awareness to what is oblivious. The finding in this study also in line with Buchalter (2004). He explained that image and symbol in sketch, drawing and other technique used in expressive arts therapy serves as vehicle to encourage sharing process, communication, growth and knowledge.

The interactions of these experiences have provided insights to researchers on the issue of youth involvement in delinquent behaviors. The subjects of the study were also found to be able to share their life experiences comfortably when they produce their life maps creativity. The sketch map of life was also shared spontaneously, 
driven by the creativity that generated by them. In line with the findings of John (2012) in his study using painting techniques such as body painting, hand painting and the town of hope, the results showed the effectiveness of using these techniques when participants undergoing art therapy sessions benefitted in terms of expressing their anger and guilt safely, managing and fostering feelings of self-consciousness. He further claimed that his study of painting techniques can apparently be used to express oneself. The present findings seem to be consistent with other research which found expressive arts were a medium for communication and as a tool to help express herself/himself (Wikström, 2005).

Overall, sharing through a sketch map of life has also been able to describe the past life experiences of each subject of study. Themes that have been uncovered and discussed are hardships, emotional disorders, negative behaviors, meaning behind the words and hope expectations have clearly given us an account of life experienced by these female teenage delinquents. Participants in this study have shared their experiences using expressive arts therapy during group counseling sessions. Sharing their previous life experiences when they were involved in delinquent behaviors through a variety of creative media and arts has definitely opened their minds. Results from the observations, interviews and diary writings that were carried out with the teenagers, depicted a renewed high awareness which changed them and a very significant difference can be seen within them. The results described above can be attributed to the findings of which have been described by Romanoff and Thompson (2006). They said art is a means of individual expression to explore the feelings and experience to create. Art also helps in forming a view on the world around them and the world within themselves (Romanoff \& Thompson, 2006) that make up a consciousness.

\section{Conclusion}

In conclusion, the researchers thought this sketch map of life technique is a new innovation in the field of counseling. The qualitative research which tried to explore and understand the life experiences of the seven teenage girls involved with delinquent behaviors using this technique has presented great implications for the counselors, researchers, communities and youth delinquents. On behalf of the counselors and counseling field, this study can serve as a reference in understanding the real experience of young people who are involved in social problems particularly delinquency. The findings of this study can also serve as a guide for those involved in counseling especially those trying to understand the use of life map sketch of expressive arts therapy used in this study.

The use of sketch map of life through expressive art therapy can be practiced by counselors because this therapy is an art and creativity that are a continuation and could be combined with any other conventional theories of the counselors' choice. Practice and continuous practical use of creative arts therapy are able to provide an experience that will be a discourse in counseling in Malaysia and applicable to local communities. Finally, this study can be used by teenage delinquents whether they are involved in delinquency or not to realize their wrongdoings. This will help them prepare for positive changes when they realize the wrongdoings in the course of life based on the produced life map sketch.

\section{References}

Ahmed, F. M., Sorour, A. S., \& El Badawy, A. A. (2014). Lived Experiences of Egyptian Female Juvenile Delinquents: Phenomenological Approach. World J. of Soc Sci, 2(1). https://doi.org/10.5430/wjss.v2n1p51

Azmawati, M. N., Hazariah, A. H. S., Shamsul, A. S., Norfazilah, A., Azimatun, N. A., \& Rozita, H. (2015). Risk taking behaviour among urban and rural adolescents in two selected districts in Malaysia. South African Family Practice, 57(3), 160-165. https://doi.org/ 10.1080/20786190.2014.977048

Buchalter, S. I. (2004). A practical art therapy. Philadea, PA: Jessica Kingsley.

Capaldi, D. M., \& Shortt, J. W. (2003). Understanding conduct problems in adolescence from a life-span perspective. In G. Adams \& M. Berzonsky (Eds.), Black well handbook of adolescence. Black well.

Choon, L. J., Hasbullah, M., Ahmad, S., \& Ling, W. S. (2013). Parental attachment, peer attachment, and delinquency among adolescents in Selangor, Malaysia. Asian Social Science, 9(15), 214. https://doi.org/10.5539/ass.v9n15p214

Creswell, J. W. (2003). Research design: Qualitative, quantitative, \& mixed method approaches. London: Sage.

Deparment of Social Welfare Malaysia. (2011). The number of juvenile offenders in the country, 2011. JKMM.

Deparment of Social Welfare Malaysia. (2012). Children who are involved in crime, 2012. JKMM.

Estrella, K. (2005). Expressive therapy: An integrated approach. In C. Malchiodi (Ed.), Expressive therapies (pp. 183-209). New York, NY: The Guilford Press. 
Giorgi, A., \& Giorgi, B. (2003). Phenomenology. In J. A. Smith (Ed.), Qualitative psychology: A practical guide to research methods (pp. 25-50). London, UK: Sage.

Graham, M., \& Sontag, M. (2001). Art as an evaluative tool: A pilot study. Art Therapy: Journal of the American Art Therapy Association, 18(1), 37-43. https://doi.org/10.1080/07421656.2001.10129451

John, D. L. (2012). Drawing As Self-Expression with Normally Functioning Adult: A 10-Week Technique (Ph.D Thesis). Lesley University.

Jung, S., \& Choi, E. (2017). Life satisfaction and delinquent behaviors among Korean adolescents. Personality and Individual Differences, 104, 104-110. https://doi.org/10.1016/j.paid.2016.07.039

Melati, S. (2005). Integrating Art Therapy with Family Therapy. Masalah Pendidikan. Universiti Malaya.

Merriam, S. B. (2001). Qualitative research and case study application in education. San.

Merriam, S. B. (2002). Qualitative research in practice. San Francisco, CA: Jossey-Bass.

Miles, M. B., \& Huberman, A. M. (1994). Qualitative data analysis (2nd ed.). London, UK: Sage.

Moran, D. (2000). Introduction to phenomenology. New York, NY: Routledge.

Mousavi, M., \& Sohrabi, N. (2014). Effects of art therapy on anger and self-esteem in aggressive children. Procedia-Social and Behavioral Sciences, 113, 111-117.

Phey, L. K., \& Lan, T. (2012) Quit Now! A Psychoeducational Expressive Therapy Group Work Approach for At-Risk and Delinquent Adolescent Smokers in Singapore. The Journal for Specialists in Group Work, 37(1), 2-28. https://doi.org/10.1080/01933922.2011.606557

Riley, S. (1999). Illustrating the family story: Art therapy a lens for viewing the family's reality. Art in Psychotherapy, 20, 254-264.

Romanoff, B. D., \& Thompson, B. E. (2006). Meaning construction in palliative care: The use of narrative, ritual and the expressive arts. American Journal of Hospice \& Palliative Medicine, 23(4), 309-316. https://doi.org/10.1177/1049909106290246

Rowe, C., Watson-Ormond, R., English, L., Rubesin, H., Marshall, A., Linton, K., Amolegbe, A., Agnew-Brune, C., \& Eng. (2016). Evaluating Art Therapy to Heal the Effects of Trauma Among Refugee Youth: The Burma Art Therapy Program Evaluation. Health Promotion Practice, 18(1), 26-33. https://doi.org/10.1177/1049909106290246

Sabitha Marican. (2005). Kaedah Penyelidikan Sains Sosial. Pearson Prentice Hall.

Saunders, E., \& Saunders, J. A. (2000). Evaluating the effectiveness of art therapy through a quantitative, outcomes-focused study. Arts in Psychotherapy, 27, 99-106.

Sh Marzety Adibah Al Sayed Mohamad \& Zakaria Mohamad. (2014). The use of expressive arts therapy in understanding psychological issues of juvenile delinquency. Asian Social Science, 10(9), 144-161. https://doi.org/10.5539/ass.v10n9p144

Sh Marzety Adibah, A. S. M., Melati, S., \& Zuria, M. (2013). Understanding the experience of female adolescent delinquents: A phenomenological study. Int. J. Soc. Sci, 5, 1-19. https://doi.org/10.7718/ijss.v5i1.392

Thomas, B. (2011). Creative expression activities for teens: Exploring identity through art, craft and journaling. Jessica Kingsley Publishers.

Wilson \& Ziomek-Daigle. (2013). The use of expressive arts as experienced by high school counselor trainees. Journal of Creativity in Mental Health, 8, 2-20. https://doi.org/10.1080/15401383.2013.763674

Wikström, B. M. (2005). Communicating via expressive arts: The natural medium of self-expression for hospitalized children. Pediatric Nursing, 31(6), 480.

\section{Copyrights}

Copyright for this article is retained by the author(s), with first publication rights granted to the journal.

This is an open-access article distributed under the terms and conditions of the Creative Commons Attribution license (http://creativecommons.org/licenses/by/4.0/). 